\title{
Effect of Soil Amendments on Physical Properties of Soil in Maize (Zea mays L.)
}

\author{
P. Laxman Rao ${ }^{1}$, G. Jayasree ${ }^{1}$, G. Pratibha ${ }^{2}$ and T. Ram Prakash ${ }^{3}$ \\ ${ }^{1}$ Department of Soil Science and Agricultural Chemistry, Professor Jayashankar \\ Telangana State Agricultural University, Hyderabad, India \\ ${ }^{2}$ CRIDA, Santhosh Nagar, India \\ ${ }^{3}$ AICRP on Weed Control, WTC, India \\ *Corresponding author
}

\section{A B S T R A C T}

\section{Keywords}

Tanksilt, biochar,

FYM,

Vermicompost,

Sandy loam,

Physical properties

and maize.

\section{Article Info}

Accepted:

26 May 2017

Available Online:

10 June 2017
A field experiment was carried out at College Farm, College of Agriculture, Rajendranagar, PJTSAU, Hyderabad, Telangana state, to evaluate the efficacy of different soil amendments on physical characteristics of soil in maize crop. The soil was sandy loam in texture. The soil moisture content of soil was increased in order of application of tanksilt > vermicompost > biochar > FYM > RDF > control. Application of tanksilt increased moisture content of soil 2.1 to $5.6 \%$ over control throughout growth period. The application of tanksilt and vermicompost significantly increased the (AWC) available water content compared to control. The application of different amendments tanksilt, vermicompost and FYM (Farm Yard Manure) along with RDF significantly decreased the bulk density compared to RDF (Recommended Dose of Fertilizers) applied plots. Almost 50\% increase in aggregate stability was observed with the application of tanksilt (28.92\%). Application of all the amendments viz., tanksilt, vermicompost, biochar and FYM reduced hydraulic conductivity to $0.020,0.029$, 0.031 and $0.028 \mathrm{~cm} \mathrm{~min}^{-1}$ respectively over the control $\left(0.034 \mathrm{~cm} \mathrm{~min}^{-1}\right)$.

\section{Introduction}

Soil having good structure, porosity, hydraulic conductivity, bulk density and strength provide good medium for growth to beneficial microorganisms, better nutrient and water movement into the soil profile, higher nutrient and water retention and more root growth ultimately provide higher yield as compared to degraded soil having poor physical properties (Abdallah et al., 1998). The vermicompost is an "organic fertilizer" produced by interactions between earthworms and soil microorganisms, resulting in a material with a high degree of maturity, high porosity, aeration, drainage and water storage capacity. The use of vermicompost promotes productive capacity of soils through improvement in physical properties (Edwards and Burrows, 1988). Biocahr is a carbonaceous product obtained through the thermal decomposition of biomass in the 
absence of oxygen or little oxygen at high temperature. It has good physical properties i.e. high porosity, large surface area (Van Zwieten et al., 2010). The physical properties like porosity, water holding capacity, bulk density and soil moisture content was improved with the application of FYM (Choudhary and Kumar, 2013). Due to application of tanksilt to soil, bulk density (BD) and hydraulic conductivity of soil was decreased, Water holding capacity (WHC) and soil moisture content was increased (Jeyamangalam et al., 2012).

\section{Materials and Methods}

\section{Experimental site and design}

A field experiment was carried out at College Farm, College of Agriculture, Rajendranagar, PJTSAU, Hyderabad, Telangana state, India. Maize variety 900-M-GOLD was cultivated during rabi 2014-15 in Randomised Block Design (RBD) with 6 treatments replicated four times. Treatments consist of $\mathrm{T}_{1-}$ vermicompost@ $5 \mathrm{tha}^{-1}, \mathrm{~T}_{2}$-FYM @ $10 \mathrm{tha}^{-1}$, $\mathrm{T}_{3}$-tanksilt @50 t ha ${ }^{-1}, \mathrm{~T}_{4}$ - biochar@10 tha ${ }^{1}, \mathrm{~T}_{5^{-}}$control (without any fertilizer), $\mathrm{T}_{6^{-}} \mathrm{RDF}$ (NPK-200, 60, $50 \mathrm{~kg} \mathrm{ha}^{-1}$ ). Recommended Dose of Fertilizers was commonly applied from treatment $T_{1}$ to $T_{4}$.

\section{Analysis of soil physical properties}

Bulk density of the experimental soil was estimated by core sampler method following the standard procedures (Klute, 1986).Gravimetric soil moisture content of the soil was estimated by gravimetric method by drying the soil in oven at $105^{\circ} \mathrm{c}$ temperature of to a constant weight. Saturated hydraulic conductivity of the soil was estimated by constant water head method (Dakshinamurthy and Gupta, 1967) at knee high and harvest stage. Aggregate stability of the soil was estimated by wet sieving method
(Yoder, 1936). $50 \mathrm{~g}$ of aggregates sieved through nests of sieves $(5,2,1,0.5,0.25$ and $0.1 \mathrm{~mm}$ ) in Yoder's apparatus. The dry aggregates from each sieve are collected, weighed and estimated for aggregate stability. Available water content of the soil was estimated by Pressure plate membrane method (Dane and Hopmans, 2002). AWC (Available water content) of soil was estimated by the difference in soil water content between field capacity (FC) and permanent wilting point (PWP). The particle size analysis was carried out by Bouyoucos hydrometer method (Piper, 1966).

Soil samples were drawn at random from 0 to $30 \mathrm{~cm}$ soil depth of experimental field and were analyzed for their physical properties by adopting standard procedures. The results were summarized in table 1.

\section{Results and Discussion}

\section{At knee high stage}

Significant decreases in bulk density were observed with the addition of tanksilt, vermicompost and FYM (Table 2). Though, slight increases in bulk density were observed from knee high stage to at harvest. The effect of various amendments in reducing the bulk density was sustained till the harvest of the crop. A perusal of the data indicates that significantly lower bulk density of $1.354 \mathrm{Mg}$ $\mathrm{m}^{-3}$ was recorded with the application of tanksilt @ $50 \mathrm{t} \mathrm{ha}^{-1}$.The application of tanksilt, vermicompost and FYM significantly decreased the bulk density $(1.354,1.356$ and $1.362 \mathrm{Mg} \mathrm{m}^{-3)}$ respectively compared to the control (1.373 $\left.\mathrm{Mg} \mathrm{m}^{-3}\right)$. The percentage decrease in bulk density was 1.4, 1.24 and $0.81 \%$ respectively, with application of tanksilt, vermicompost and FYM. The application of biochar and RDF resulted in decrease in bulk density (1.366 and $1.372 \mathrm{Mg}$ $\left.\mathrm{m}^{-3}\right)$ which was on par with the control (1.373 
$\mathrm{Mg} \mathrm{m}^{-3}$ ). The reduction in bulk density by organics may be due to the improvement of aggregation and structure inturn improves porosity of soil which has direct influence on the bulk density of the soil (Ganiger et al., 2012).

The application of different amendments viz., tanksilt, vermicompost and FYM along with RDF significantly decreased the bulk density compared to the RDF alone but the application of biochar along with RDF was on par with application of RDF alone. A reduction in bulk density in different soils was reported by several workers (Alburquerque, 2013 and Karer et al., 2013) with application of biochar whereas in the present study it was not significant. This may be due to low level i.e., < $0.5 \%(\mathrm{w} / \mathrm{w})$ of soil/biochar was applied here. The addition of finely divided peat like material 'vermicompost' increased the porosity of the soil and hence decreased the bulk density (Ghosh et al., 2013).The application of tanksilt significantly decreased the bulk density compared to biochar application but it was on par with vermicompost and FYM application.

\section{At harvest}

A perusal of the data indicates that significantly lower bulk density of $1.359 \mathrm{Mg}$ $\mathrm{m}^{-3}$ was recorded with the application of tanksilt @ $50 \mathrm{t} \mathrm{ha}{ }^{-1}$. The application of tanksilt, vermicompost and FYM significantly decreased the bulk density $(1.359,1.363$ and $1.362 \mathrm{Mg} \mathrm{m}^{-3}$ ) respectively compared to the control (1.38 $\left.\mathrm{Mg} \mathrm{m}^{-3}\right)$. The percentage decrease in bulk density was 1.53, 1.24 and $1.31 \%$ respectively. The application of biochar and RDF results in bulk density (1.371 and $1.377 \mathrm{Mg} \mathrm{m}^{-3)}$ which was on par with the control $\left(1.38 \mathrm{Mg} \mathrm{m}^{-3}\right)$. The application of different amendments viz., tanksilt, vermicompost and FYM along with RDF significantly decreased the bulk density compared to the RDF alone but the application of biochar along with RDF was on par with application of RDF alone. The application of tanksilt significantly decreased the bulk density compared to biochar application but it was on par with vermicompost and FYM application.

\section{Hydraulic conductivity}

\section{At knee high stage}

Data pertaining to the hydraulic conductivity at knee high stage and harvest was presented in table 3 . The hydraulic conductivity at knee high stage ranged between 0.017 to $0.034 \mathrm{~cm}$ $\mathrm{min}^{-1}$. The highest being recorded in control $\left(0.034 \mathrm{~cm} \mathrm{~min}^{-1}\right)$ followed by RDF applied plots $\left(0.032 \mathrm{~cm} \mathrm{~min}^{-1}\right)$. Application of all the amendments reduced hydraulic conductivity. Almost $50 \%$ reduction in hydraulic conductivity was observed with the application of tanksilt $\left(0.017 \mathrm{~cm} \mathrm{m^{-1 }}\right)$. Among the amendments hydraulic conductivity in the order of biochar > vermicompost > FYM > tanksilt. Annadurai (2011) reported that application of tanksilt increased the water holding capacity thereby hydraulic conductivity was reduced to the minimum value.

\section{At harvest}

In general the hydraulic conductivity values were similar to that of a knee high stage except a slight increase of 0.002 to $0.003 \mathrm{~cm}$ $\min ^{-1}$ was observed in the all the treatments. The hydraulic conductivity at harvest ranged between 0.020 to $0.034 \mathrm{~cm} \mathrm{~min}^{-1}$. The highest is being recorded in control $\left(0.034 \mathrm{~cm} \mathrm{~min}^{-1}\right)$. Application of all the amendments reduced hydraulic conductivity. Almost 50\% reduction in hydraulic conductivity was observed with the application of tanksilt $\left(0.020 \mathrm{~cm} \mathrm{~min}^{-1}\right)$. Among the amendments hydraulic conductivity is in the order of biochar > 
vermicompost $>$ FYM $>$ tanksilt. Application of a laboratory produced biochar from black locust increased the available water capacity by $97 \%$ and saturated water content by $56 \%$ but reduced hydraulic conductivity (Uzoma et al., 2011).

A slight increase of hydraulic conductivity was observed from knee high stage. The decrease in hydraulic conductivity due to application of amendments may be attributed to improvement of microporosity due to clay addition (tanksilt) or better aggregation by vermicompost, FYM and biochar.

\section{Available water content}

\section{At knee high stage}

Field capacity and permanent wilting point values were determined by pressure plate apparatus and the difference in volumetric moisture content between these two were calculated at knee high stage and at the harvest. Close examination of data (Table 4) indicates that significantly higher available water content of $11.52 \%$ was recorded with the application of tanksilt @ $50 \mathrm{t} \mathrm{ha}^{-1}$.

The tanksilt application improved the clay content in the plough layer which had direct bearing on improving available water content (Bhanavase et al., 2011). Studies by Osman, 2008 also demonstrated that addition of tanksilt @ 50, 100, 150 and 375 tractor load ha-1 improved the available water content by $0.2,0.7,1.2$ and $3.2 \%$, respectively.

The application of tanksilt and vermicompost significantly increased the available water content (2.5 and $1.48 \%)$ respectively, compared to the control (9.02 \%). The application of biochar, FYM and RDF resulted in available water content of (9.14, 9.43 and $9.29 \%$ ) respectively, which was on par with the control. Biochar application increased the water retention capacity of the soil because it increased soil porosity and also due to adsorptive nature of biochar (Herath et al., 2013). However in the present study statistically significant increase in available water content due to the biochar addition was not observed. Tryon (1948) reported that application of charcoal increased AWC in sandy soil, no effect in a loam soil, and decreased moisture content in a clay soil. Such a response may be due to attributed to the hydrophobic nature of the charcoal. Because the soil moisture retention may only be improved in coarse - textured soils, a careful choice of biochar/soil combination needs to be taken into consideration.

Table.1 Initial soil physical properties

\begin{tabular}{|l|l|}
\hline Soil physical property & values \\
\hline Textural class & Sandy loam \\
\hline a) Sand (\%) & 75.6 \\
\hline b) Silt (\%) & 8.0 \\
\hline c) Clay (\%) & 16.4 \\
\hline Bulk density $\left(\mathrm{Mg} \mathrm{m}^{-3}\right)$ & 1.37 \\
\hline Hydraulic conductivity (cm min $\left.^{-1}\right)$ & 0.037 \\
\hline Available water content $(\%)$ & 9.03 \\
\hline Aggregate stability (\%) & 18.88 \\
\hline Soil moisture content $(\%)$ & 7.00 \\
\hline
\end{tabular}


Fig.1 Soil amendments impact on gravimetric moisture content throughout the crop growth period

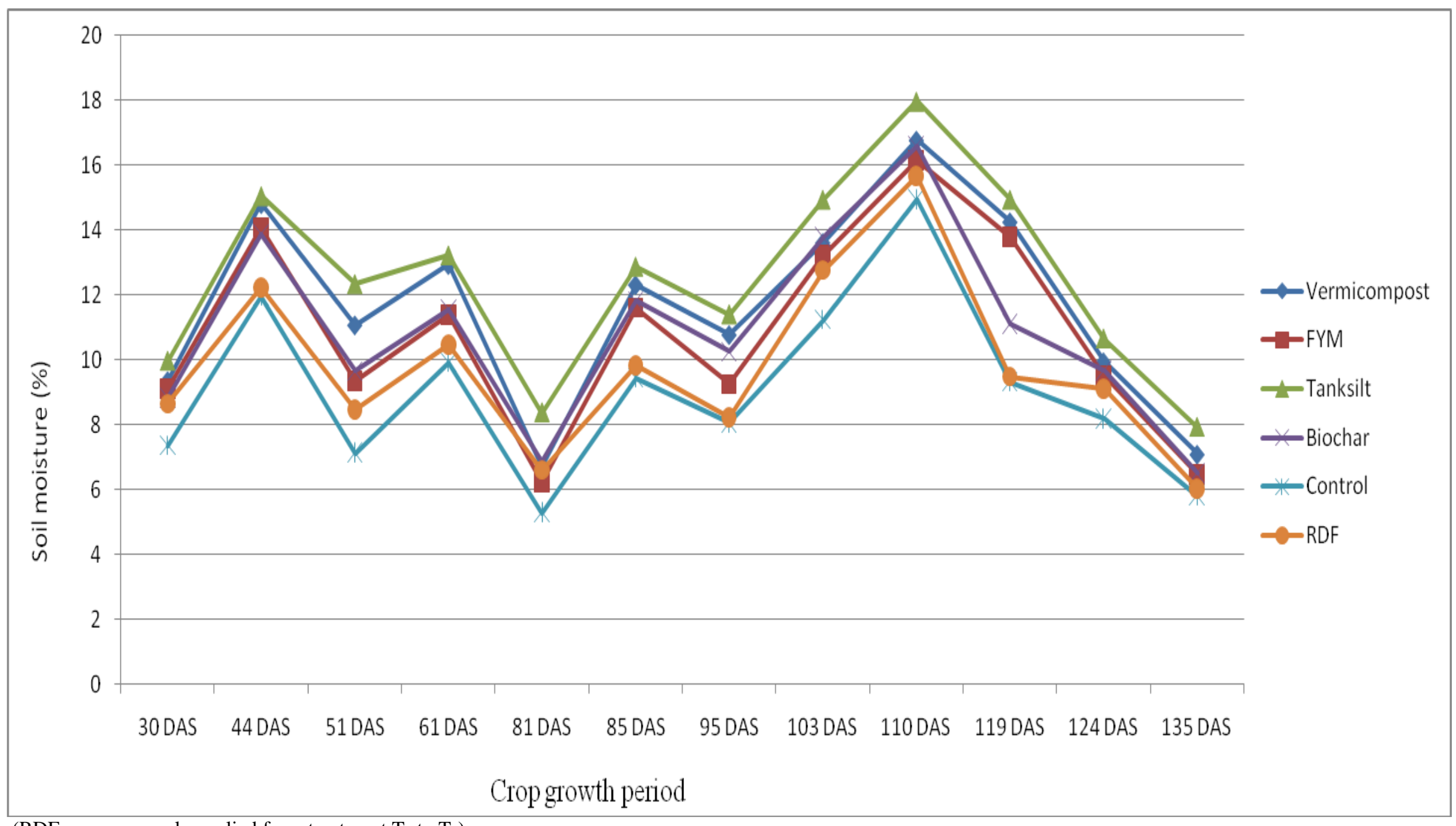

(RDF was commonly applied from treatment $\mathrm{T}_{1}$ to $\mathrm{T}_{4}$ ) 
Table.2 Soil amendments impact on bulk density $\left(\mathrm{Mg} \mathrm{m}^{-3}\right)$ at knee high stage and At harvest of maize

\begin{tabular}{|l|c|c|}
\hline \multirow{2}{*}{ Treatments } & \multicolumn{2}{|c|}{ Bulk density } \\
\cline { 2 - 3 } & Knee high stage & Harvest \\
\hline $\mathrm{T}_{1}:$ Vermicompost & 1.355 & 1.363 \\
\hline $\mathrm{T}_{2}:$ FYM & 1.362 & 1.362 \\
\hline $\mathrm{T}_{3}:$ Tanksilt & 1.354 & 1.359 \\
\hline $\mathrm{T}_{4}:$ Biochar & 1.366 & 1.368 \\
\hline $\mathrm{T}_{5}:$ Control & 1.373 & 1.373 \\
\hline $\mathrm{T}_{6}: \mathrm{RDF}$ & 1.372 & 1.372 \\
\hline $\mathrm{CD}(\mathrm{P}=0.05)$ & 0.007 & 0.007 \\
\hline $\mathrm{SEm} \pm$ & 0.0026 & 0.0026 \\
\hline
\end{tabular}

(RDF was commonly applied from treatment $\mathrm{T}_{1}$ to $\mathrm{T}_{4}$ )

Table.3 Soil amendments impact on hydraulic conductivity $\left(\mathrm{cm} \mathrm{min}^{-1}\right)$ at knee high stage and At harvest of maize

\begin{tabular}{|l|c|c|}
\hline \multirow{2}{*}{ Treatments } & \multicolumn{2}{|c|}{ Hydraulic conductivity } \\
\cline { 2 - 3 } & $\begin{array}{c}\text { Knee high } \\
\text { stage }\end{array}$ & Harvest \\
\hline $\mathrm{T}_{1}:$ Vermicompost & 0.027 & 0.029 \\
\hline $\mathrm{T}_{2}:$ FYM & 0.026 & 0.028 \\
\hline $\mathrm{T}_{3}:$ Tanksilt & 0.017 & 0.020 \\
\hline $\mathrm{T}_{4}:$ Biochar & 0.029 & 0.031 \\
\hline $\mathrm{T}_{5}:$ Control & 0.034 & 0.034 \\
\hline $\mathrm{T}_{6}:$ RDF & 0.032 & 0.032 \\
\hline $\mathrm{CD}(\mathrm{P}=0.05)$ & 0.005 & 0.004 \\
\hline $\mathrm{SEm} \pm$ & 0.001 & 0.001 \\
\hline
\end{tabular}

(RDF was commonly applied from treatment $\mathrm{T}_{1}$ to $\mathrm{T}_{4}$ )

Table.4 Soil amendments impact on soil available water content (\%) at knee high stage and At harvest of maize

\begin{tabular}{|l|c|c|}
\hline \multirow{2}{*}{ Treatments } & \multicolumn{2}{|c|}{ Available water content (\%) } \\
\cline { 2 - 3 } & Knee high stage & Harvest \\
\hline $\mathrm{T}_{1}:$ Vermicompost & 10.50 & 10.81 \\
\hline $\mathrm{T}_{2}:$ FYM & 9.43 & 9.33 \\
\hline $\mathrm{T}_{3}:$ Tanksilt & 11.52 & 11.20 \\
\hline $\mathrm{T}_{4}:$ Biochar & 9.14 & 9.14 \\
\hline $\mathrm{T}_{5}:$ Control & 9.02 & 9.02 \\
\hline $\mathrm{T}_{6}: \mathrm{RDF}$ & 9.29 & 9.10 \\
\hline $\mathrm{CD}(\mathrm{P}=0.05)$ & 1.01 & 0.97 \\
\hline $\mathrm{SEm} \pm$ & 0.33 & 0.32 \\
\hline
\end{tabular}

(RDF was commonly applied from treatment $\mathrm{T}_{1}$ to $\mathrm{T}_{4}$ ) 
Table.5 Soil amendments impact on aggregate stability (\%) at knee high stage and At harvest of maize

\begin{tabular}{|l|c|c|}
\hline \multirow{2}{*}{ Treatments } & \multicolumn{2}{|c|}{ Aggregate stability (\%) } \\
\cline { 2 - 3 } & Knee high stage & Harvest \\
\hline $\mathrm{T}_{1}:$ Vermicompost & 22.48 & 23.45 \\
\hline $\mathrm{T}_{2}:$ FYM & 20.36 & 21.01 \\
\hline $\mathrm{T}_{3}:$ Tanksilt & 27.98 & 28.92 \\
\hline $\mathrm{T}_{4}:$ Biochar & 25.09 & 26.95 \\
\hline $\mathrm{T}_{5}:$ Control & 18.90 & 19.95 \\
\hline $\mathrm{T}_{6}: \mathrm{RDF}$ & 21.03 & 20.42 \\
\hline $\mathrm{CD}(\mathrm{P}=0.05)$ & 2.12 & 2.77 \\
\hline $\mathrm{SEm} \pm$ & 0.7 & 0.91 \\
\hline
\end{tabular}

(RDF was commonly applied from treatment $\mathrm{T}_{1}$ to $\mathrm{T}_{4}$ )

Tanksilt and vermicompost significantly increased the available water content compared to the RDF alone but the application of FYM and biochar was on par with application of RDF alone. The application of tanksilt significantly increased the available water content compared to vermicompost, FYM and biochar application.

\section{At harvest}

A perusal of the data indicates that significantly higher available water content of $11.20 \%$ at harvest was recorded with the application of tanksilt @50 t ha ${ }^{-1}$. The application of tanksilt and vermicompost significantly increased the available water content $(2.18$ and $1.79 \%)$ respectively compared to the control $(9.02 \%)$. The application of biochar, FYM and RDF results in available water content $(9.14,9.33$ and 9.10 $\%)$ which was on par with the control. Soil water holding capacity and total porosity (\%) increased with an increase in the ratio of vermicompost applied because vermicompost itself has a high WHC and increased porosity because it creates larger aggregates with larger air spaces in between them when it is mixed with soil (Nada et al.,2011).

The application of different amendments viz., tanksilt and vermicompost along with RDF significantly increased the available water content compared to the RDF alone but the application of FYM and biochar along with RDF was on par with application of RDF alone. The application of tanksilt significantly increased the available water content compared to vermicompost, FYM and biochar application.

\section{Aggregate stability}

\section{At knee high stage}

The aggregate stability at knee high stage ranged between 20.90 to $27.98 \%$ (Table 5). The highest being recorded in tanksilt applied plots $(27.98 \%)$ followed by vermicompost applied plots $(22.48 \%)$ and lowest in the control $(20.90 \%)$.

Application of all the amendments increased the aggregate stability. Almost 50\% increase in aggregate stability was observed with the application of tanksilt $(27.98 \%)$.

Among the amendments aggregate stability increased in the order of tanksilt > vermicompost > biochar > FYM. Oades (1984) reported that organic matter addition increased the stability of macro aggregates through the binding of the soil mineral particles by polysaccharides. 


\section{At harvest}

The aggregate stability at harvest followed same trend as that of a knee high stage except slight decrease was observed. The aggregate stability at harvest ranged between 19.95 to $28.92 \%$. The highest being recorded in tanksilt applied plots (28.92\%) followed by vermicompost applied plots $(23.45 \%)$ and lowest in the control (19.95\%). Application of all the amendments increased the aggregate stability. Almost 50\% increase in aggregate stability was observed with the application of tanksilt (28.92 \%). Among the amendments aggregate stability increased in the order of tanksilt > vermicompost > biochar > FYM. Application of biochar increased the aggregate stability compared to the control. Increase in aggregate stability was probably associated with the formation of water-stable macroaggregates by the application of biochar (Herath et al., 2013).

\section{Soil moisture content}

Gravimetric soil moisture content at regular intervals throughout crop growth period was monitored and was presented in Figure 1. From the data it was evident that highest moisture content was observed in tanksilt applied plots followed by vermicompost applied plots and lowest being the control i.e., without any fertilizer application. The moisture content was increased in the order of tanksilt > vermicompost > biochar > FYM $>$ RDF > control.

Application of tanksilt improved the moisture holding capacity of the soil and hence an increase of 2.1 to $5.6 \%$ moisture content over the control was observed throughout crop growth period. The results were in line with results obtained by Rao et al., 2013 who found that $2.77 \%$ increase in soil moisture content by application of tanksilt @ $60 \mathrm{t} \mathrm{ha}^{-1}$ in soils of rainfed conditions. The increase in moisture content by application of tanksilt was due to its high water retention capacity $(11.5 \%)$ and tanksilt in their study contained $0.3 \%$ organic carbon (Rao et al., 2013). In the present study, the organic carbon of applied tanksilt is $0.3 \%$. Studies by Osman, 2008 also demonstrated that addition of tanksilt @ 50, 100, 150 and 375 tractor load ha ${ }^{-1}$ improved the available water content by $0.2,0.7,1.2$ and $3.2 \%$, respectively. The increase in root zone gravimetric moisture content by $1 \%$ by application of 100 tractor loads $\mathrm{ha}^{-1}$ of tanksilt was recorded by Osman, 2008. Significant increase in moisture content was observed with application of vermicompost @ $5 \mathrm{t} \mathrm{ha}^{-1}$ over the control and RDF however it was on par with that of tanksilt application. Studies by Gutierrez et al., (2007), Fauziah and Agamuthu (2009) have shown that average water holding capacity of vermicompost was $25 \%$ while its total organic content was 12 $\%$.

Though an increase in gravimetric moisture content of 1 to $2 \%$ was observed by application of FYM and biochar but it was statistically on par with RDF and control plots. The application of different amendments improved WHC of the soil and hence more uptake of water and nutrients which inturn reflected by dry matter production and ultimately the yield of the crop.

The results indicate that the addition of tanksilt and vermicompost significantly improved moisture content of the soil and hence the irrigation interval may be enhanced. So, that the water requirement of the crop was reduced.

Application of soil amendments improved soil physical environment and inturn improved yield of maize crop. From the experiment, it was found that application of tanksilt @ $50 \mathrm{t}$ $\mathrm{ha}^{-1}$ resulted in good soil physical conditions compared to vermicompost, FYM, biochar, 
RDF and control. The gravimetric soil moisture content was increased in order of tanksilt > vermicompost > biochar > FYM > RDF > control. Application of tanksilt increased moisture holding capacity of soil 2.1 to $5.6 \%$ over control throughout growth period. The application tanksilt and vermicompost significantly increased the (AWC) available water content (2.5 and $1.48 \%)$ respectively compared to control $(9.02 \%)$. However the application of biochar, FYM and RDF resulted in AWC of (9.14, 9.43 and 9.29\%) which was on par with the control. The application of different amendments tanksilt, vermicompost and FYM along with RDF significantly decreased the bulk density compared to RDF applied plots. Significant increase in stability of aggregates was noticed in tanksilt, vermicompost, biochar and FYM application over control (19.95\%). Application of all the amendments viz., tanksilt, vermicompost, biochar and FYM reduced hydraulic conductivity to $0.020,0.029,0.031$ and 0.028 $\mathrm{cm} \mathrm{min}^{-1}$ respectively over the control $(0.034$ $\left.\mathrm{cm} \min ^{-1}\right)$.

\section{References}

Abdallah, I.H.M., Alawneh, A. and Abusafaqan. O. 1998. Effects of organic matter matter on the physical and the physicochemical properties of an illitic soil. J. Applied Clay Science. pp. 257278.

Alburquerque, J.A., Salazar, P., Barron, V., Torrent, J., Campillo, M.C., Gallardo, A and Villar, R. 2013. Enhanced wheat yield by biochar addition under different mineral fertilization levels. Agronomy for Sustainable Development. 33: 475-484.

Annadurai, B. 2011.Theri- soil reclamation using tanksilt in tuticorin district. Indian Journal of Environmental Protection. 31(8): 679-683.

Bhanavase, D.B., Thorve1, S.B., Upadhye, S.K., Kadam, J.R and Osman, M. 2011. Effect of Tank Silt Application on Productivity of rabi Sorghum and Soil Physico-Chemical Properties. Indian
Journal of Dryland Agricultural Research and Development. 26(2): 82-85.

Choudhary, V.K and Suresh Kumar, P. 2013. Maize production, economics and soil productivity under different organic source of nutrients in eastern himalayan region, India. International Journal of Plant Production.7 (2):167-186.

Dakshinamurthy, C and Gupta, R. 1967. Practical manual in soil physics, IARI, Pusa, New delhi.

Dane, J.H and Hopmans, J.W., 2002. Water retention and storage. Methods of Soil Analysis. Part. 4. SSSA Book Ser. 5. Soil Science Society of America, Madison, WI. pp. 671-796.

Edwards, C.C and Burrows, I. 1988. The Potential of Earth-worm Composts as Plant Growth Media, In: C. A. Ed-wards, E. F. Neuhauser, Eds., Earthworms in Environ-mental and Waste Management, SPB Academic Publi- cation, The Netherlands. pp. 211-220.

Fauziah, S.H and Agamuthu, P. 2009. Sustainable household organic waste management via vermicomposting. Malaysian Journal of Science, 28 (2): 135-142.

Ganiger, V. M., Mathad, J. C., Madalageri, M. B., Babalad, H. B.,Hebsur N. S and Yenagi, N. B. 2012. Effect of organics on the physico-chemical properties of soil after bell pepper cropping under open field condition. Karnataka Journal of Agricultural Sciences. 25 (4): 479-484.

Ghosh, B. C., Bera, N., Das, D and Swain, D. K. 2013. Effect of Varying Soil and Vermicompost Mixtures on Growing Media and Yield and Quality of Sweet Corn. International Conference on Food and Agricultural Sciences. 55(8):38-42.

Gutierrez, F.A.M., Borraz, J.S., Molina, M., J.A., Nafate, C.C., Archila, M.A., Oliva, M.A.O, Rosales, $\mathrm{R}$ and Deendoven L. 2007. Vermicompost as a soil supplement to improve growth, yield and fruit quality of tomato (Lycopersicum esculentum). Biore Tech., 98: 2781-2786.

Herath, H.M.S.K., Arbestain, M.C and Hedley, 
M. 2013. Effect of biochar on soil physical properties in two contrasting soils: An Alfisol and an Andisol. Geoderma. 209-210:188-197.

Jeyamangangalam, F., Annadurai, B and Arunachalam, N. 2012. Effect of Tank Silt as organic amendment on physical properties of Theri soil using Groundnut (Arachis hypogeal L.). Journal of Soils and crops. 22(1):10-14.

Karer, J., Wimmer, B., Zehetner, F., Kloss, S and Soja, G. 2013. Biochar application to temperate soils: Effects on nutrient uptake and crop yield under field conditions. Agricutural and food science. 22: 390403.

Klute, A. 1986. Porosity. In Methods of soil analysis- part 1(ed. C.A. Black). Physical and mineralogical methods. American Society of Agronomy inc., SSSA, IC, Madison/Wisconsin, USA.

Nada, W. M., Rensburg, L.V., Claassens, S and Blumenstein, O. 2011. Effect of Vermicompost on Soil and Plant Properties of Coal Spoil in the Lusatian Region (Eastern Germany). Institute of Earth and Environmental Sciences, Potsdam University, Potsdam, Germany.

Oades, J.M.1984. Soil organic matter and structural stability mechanisms and implications for management. Plant and Soil. 76: 319-337.

Osman, M. 2008. Recycling of tank silt for improving soil and water productivity in rainfed areas. Lecture Notes for the Winter School on "Technological
Advances in Conservation of Natural Resources in Rainfed Agriculture", Central Research Institute for Dryland Agriculture, Hyderabad.

Piper, C.S. 1966. Soil and Plant analysis. Intl. Sci. Pub. New York. 47-49.

Rao, CH. S., Jakkula, V. S., Kundu, S., Kasbe, S. S., Veeraiah, R., Rammohan, S., Dixit, S., Dinesh babu, $\mathrm{M}$ and Venkanna, K. 2013. Management of intermittent droughts through on-farm generation of organic matter: Participatory experiences from rainfed tribal districts of Andhra Pradesh. Journal of Agrometeorology. 15(2):140-145.

Tryon, E.H. 1948. Effect of charcoal on certain physical, chemical, and biological properties of forest soils. Ecological Monographs. 18: 81-115.

Uzoma, K.C., Inoue, M., Andry, H., Zahoor, A and Nishihara, E. 2011. Influence of biochar application on sandy soil hydraulic properties and nutrient retention. J. Food Agricultural and Environment. 9: 1137-1143.

Van Zwieten, L., Morris, S., Chan, K.Y., Dowine, A., Rust, J., Joseph, S. and Cowie, A. 2010. Effects of biochar from slow pyrolysis of paper mill waste on agronomic performance and soil fertility. Plant Sci. 327:235-246.

Yoder, R.E., 1936. A direct method of aggregate analysis of soils and a study of the physical nature of erosion losses. Journal of the American Society of Agronomy. 28, 337-351.

\section{How to cite this article:}

Laxman Rao, P., G. Jayasree, G. Pratibha and Ram Prakash, T. 2017. Effect of Soil Amendments on Physical Properties of Soil in Maize (Zea mays L.). Int.J.Curr.Microbiol.App.Sci. 6(6): 20822091. doi: https://doi.org/10.20546/ijcmas.2017.606.247 